\title{
特集一圧力誘起分子解離の最前線 -
}

\section{希ガス固体の金属化実験}

Experiments on the Metallization of Rare Gas Solids under High Pressure

\section{竹村謙一}

\section{Takemura Kenichi}

Experimental aspects of pressure-induced metallization and structural change of rare gas solids are reviewed. The metallization process of xenon, which has been extensively investigated through optical measurements, is described in more detail as an example.

[rare gas solids, DAC, metallization]

1.はじめに

希ガス元素は低温または高圧下で fcc の結晶となる (ヘリウムにはfcc 相以外に bcc 相, hcp 相が存在する)。 これらの結晶（希ガス固体）は原子がファンデアワー ルスカによってゆるやかに結合した絶縁体である[1]。

Table 1 に各元素の室温での固化圧力とバンドギャップ をあげる。希ガス固体も十分高い圧力下では原子間が 接近し、電荷移動が生じて金属化することが期待され る。希ガス原子の最外款軌道は満ちており、バンド構 造的には価電子帯が埋まっている。従って希ガス固体 の金属化は価電子帯が一つ上の空のバンドとオーバー ラップすることによって生じる。別の見方をすれば価 電子 (ヘリウム以外の希ガスでは $\mathrm{p}$ 電子) が一つ上の 空のバンド(ヘリウム以外の希ガスでは $\mathrm{d}$ 電子バンド) に移る一種の電子転移によって金属化が起こることに なる。希ガス固体の高圧下での金属化は圧力誘起分子 解離ではない。だが原子（分子）の結合様式がファン デアワールス結合から金属結合に変化する点では分子 性結晶の高压下での変化と類似性があり、圧力誘起分 子解離（共有結合とファンデアワールスカへの圧力効 果）を考えるうえで参考になるだろう。以下、現在ま でにおこなわれた実験をまとめてみた。キセノンの圧 力誘起金属化については浅海による簡潔な解説がある [2]。初期の段階での解説なのでやや古いが参照してほ しい。
Table 1. Solidifying pressures at room temperature and energy band gaps at low temperature of rare gas solids $[1,26]$.

\begin{tabular}{llc}
\hline \hline Element & $\mathrm{P}_{\mathrm{S}}(\mathrm{GPa})$ & $\mathrm{E}_{\mathrm{g}}(\mathrm{eV})$ \\
\hline $\mathrm{He}$ & 11.7 & - \\
$\mathrm{Ne}$ & 4.75 & 21.7 \\
$\mathrm{Ar}$ & 1.36 & 14.2 \\
$\mathrm{Kr}$ & 0.85 & 11.6 \\
$\mathrm{Xe}$ & 0.42 & 9.3 \\
\hline \hline
\end{tabular}

2. キセノン

希ガスの場合にも重い元素ほど低圧力で金属化する という一般則がおおむねなりたつと考えられ、希ガス の金属化の実験はキセノンから開始された。1979 年に コーネル大学の Nelson と Ruoff は低温で固化させたキ セノンにダイヤモンド針 (diamond indentor) を使って 圧力を加え、電気抵抗を測定して $32 \mathrm{~K}, 33 \mathrm{GPa}$ で金属 化を観測したと発表した[3]。この実験に刺激され多く の高圧実験がダイヤモンドアンビルセルを用いて行わ

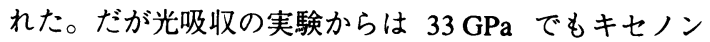
は絶縁体であり [4 - 7]、またバンド計算からキセノン の金属化圧力は少なくとも $100 \mathrm{GPa}$ 以上であることが 報告された[8]。したがってキセノンの電気抵抗の測定 
結果にはなんらかの間違い（抵抗測定または圧力值の 見積りちがい）があることがあきらかとなった[9]。55 $\mathrm{GPa}$ までのキセノンの光吸収実験から得られた光学ギ ヤップの圧力依存性を外挿するとバンドギャップがゼ 口となる圧力（金属化圧力）は 100 - $200 \mathrm{GPa}$ と予想 された。1980 年代初頭にはキセノンの金属化一番乗り をめざす実験が集中した。

fcc キセノンは常圧では $\Gamma$ 点に $9.3 \mathrm{eV}$ の直接型バン ドギャップ $\left(\Gamma_{1}-\Gamma_{15}\right)$ をもつ。この直接ギャップは 圧力下で増加するが、高圧下では伝導帯の X 点のエネ ルギーが相対的に下がってくるため、1.3 GPa 以上で のバンドギャップは間接型 $\left(\mathrm{X}_{1}-\Gamma_{15}\right)$ となる。Fig. 1 に計算で求められた直接ギャップ、間接ギャップの圧 力変化をモル体積の関数として示す $[8]$ 。間接ギャップ は圧力とともに単調に滅少する。ダイヤモンドセルに よる高圧実験ではキセノンの間接ギャップがダイヤモ ンドの吸収端（5.5 eV）以下になる $30 \mathrm{GPa}$ 以上ではじ めてこれが観測にかかる。

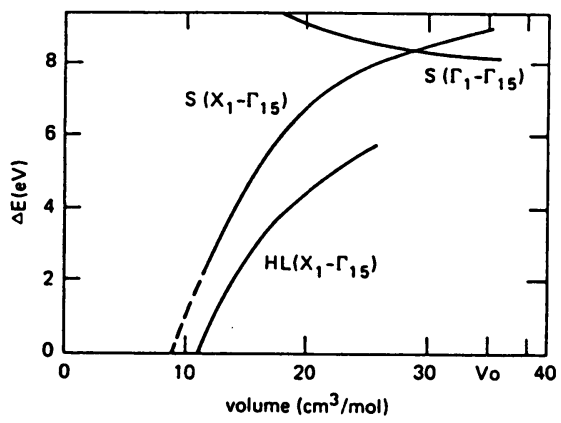

Fig. 1. Calulated energy band gap of fcc xenon as a function of volume [8]. S and HL refer to calculations using Slater and Hedin-Lundqvist exchange-correlation potentials, respectively.

光学的測定とならんでキセノンの高圧X線回折実験 も競って行なわれた。初期の実験ではキセノンは高圧 下でも fcc 構造を保つとされたが $[10,11] 、 1987$ 年に Jephcoat らによってなされた粉末 X 線回折実験では 14 $\mathrm{GPa}$ 以上で結晶構造が fcc から中間相（最密充填構 造？）へ、さらに $75 \mathrm{GPa}$ で hcp 相へ変わることが明 かになった [12]。したがって fcc 構造のみを仮定して 行われた高圧下のキセノンのバンド計算も再考をせま

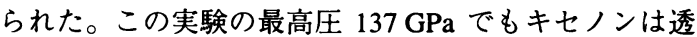
明であった。

1989 年 Goettel ら [13] および Reichlin ら [14] はほほ 同時にキセノンの光吸収・光反射実験の結果を発表し、 それぞれ $132 \mathrm{GPa} 、 150 \mathrm{GPa}$ でキセノンが金属状態に なったと報告した。Figs. 2, 3 にそれぞれのデー夕を示 す。Goettel らは $132 \mathrm{GPa}$ 付近でキセノンのバンドギャ ップがゼロになること、またこの圧力以上で赤外反射 率が圧力とともに増大していくことからキセノンは金 属状態になったと結論している。Fig. 2 に見られるよ うに金属状態の光吸収スペクトルには $2 \mathrm{eV} に$ に新しい 吸収帯があらわれる。この吸収帯は Reichlin らのデー 夕にも見られる。興味ある点はそのピーク位置（ 2 eV）は圧力をあげてもほとんど動かなかいことである。 Reichlin らはさらにX線回折実験を $172 \mathrm{GPa}$ まで行 ない $90 \mathrm{GPa}$ 以上でキセノンは hcp 構造であることを 確認した。hcp 構造に対し彼らがおこなったバンド計 算（Fig. 4）から $2 \mathrm{eV}$ の吸収は $\Gamma$ 点でのバンド間遷移
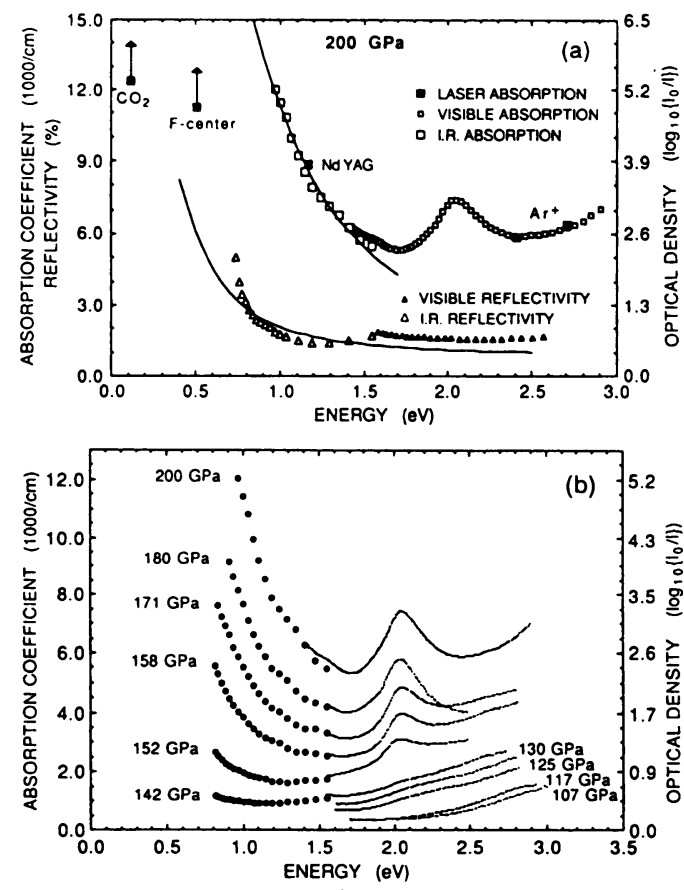

Fig. 2. Absorption and reflection spectra of xenon at high pressures from Ref. [13]. 

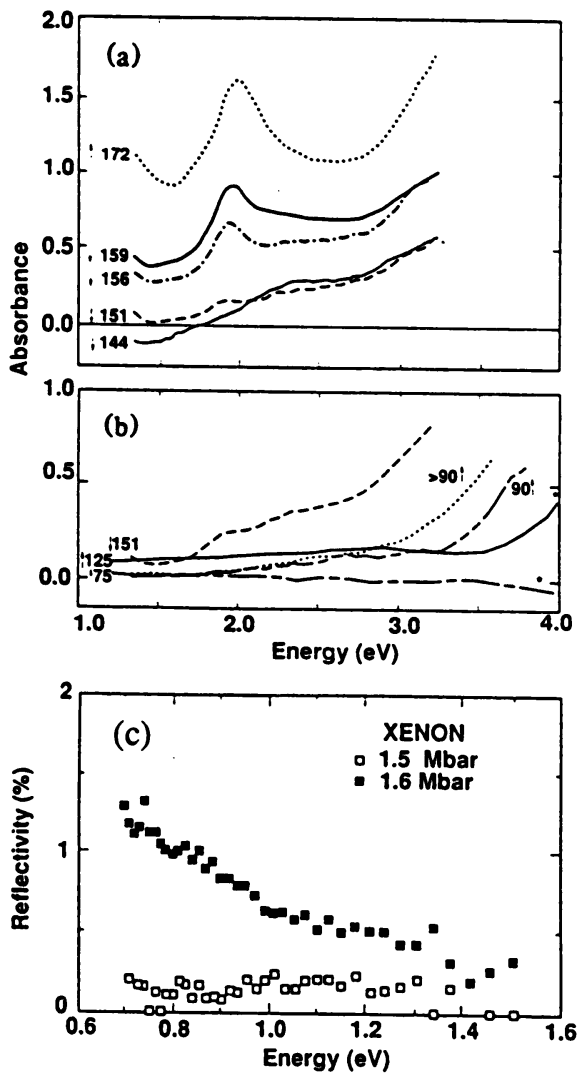

Fig. 3. Absorption and reflection spectra of xenon at high pressures from Ref. [14]. Pressures are indicated for each spectrum in (a) and (b) in GPa.

$\left(\Gamma_{5}{ }^{+} \rightarrow \Gamma_{6}{ }^{-}, \Gamma_{2}^{-}\right)$に対応すると考えられ、逆にこ の遷移が起きるためには上部のバンド $\left(\Gamma_{6}^{-}, \Gamma_{2}^{-}\right)$が 㞬いていること、すなわちこのバンドが伝導帯となっ ていることが必要であり、あらためてキセノンが金属 状態にあることが示された [14]。しかし Figs. 2,3 に 見るように「金属状態」のキセノンの可視光反射率は せいぜい数\%であり吸収係数も小さくキセノンはほほ 透明のままである。すなわち金属化したキセノンはキ ヤリヤ濃度の小さな”悪い”金属であることが結論さ れる。いうなればバンドオーバーラップによって金属 化したキセノンは典型的な金属とはほど遠い半金属で あろう。ともかくこれらの実験は $150 \mathrm{GPa}$ 付近でのキ セノンの金属化をほほ確定的とし、以降これに続く実 験は行われていない。

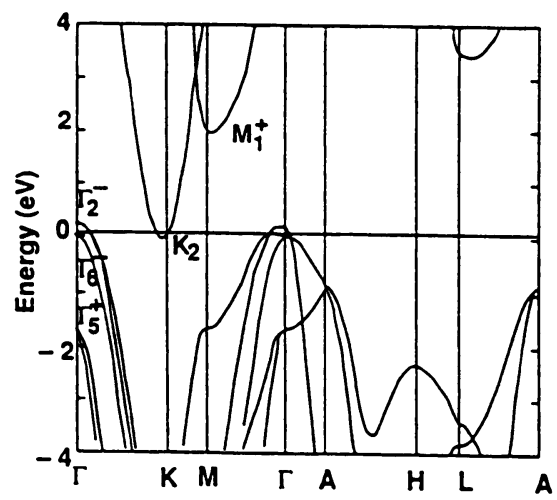

Fig. 4. Calculated energy band of hcp xenon around metallization pressure [14].

3.ネオン、アルゴン、クリプトン

キセノン以外の希ガス固体ではこれまでに金属化の 報告はない。そもそもこれらの希ガス固体はキセノン よりさらに大きなバンドギャップをもっているため、 高圧下での光吸収実験もおこなわれていない。Table 2 に希ガス固体の金属化圧力の計算値、絶縁体状態での 最外款電子配置、および金属状態で予想される伝導帯 の電子状態をあげた。

アルゴン、クリプトン、キセノンでは最外殼の $\mathrm{p}$ 電 子軌道が同じ主量子数の $\mathrm{d}$ 電子軌道と混成して伝導帯 を形成すると考えられるため、金属化圧力にも一種の スケーリング則がなりたつことが予想される。これに

Table 2. Calculated metallization pressures and electronic configurations for insulating and metallic states of rare gas solids.

\begin{tabular}{lcccc}
\hline \hline Element & $P_{m}$ & Insulator & Metal & Ref. \\
\hline $\mathrm{He}$ & $11.2 \mathrm{TPa}$ & $1 \mathrm{~s}^{2}$ & $(1 \mathrm{~s} 2 \mathrm{p})^{2}$ & {$[15]$} \\
$\mathrm{Ne}$ & $158 \mathrm{TPa}$ & $2 \mathrm{p}^{6}$ & $(2 \mathrm{p} 3 \mathrm{~d})^{6}$ & {$[16]$} \\
& $134 \mathrm{TPa}$ & & & {$[17]$} \\
$\mathrm{Ar}$ & $430 \mathrm{GPa}$ & $3 \mathrm{p}^{6}$ & $(3 \mathrm{p} 3 \mathrm{~d})^{6}$ & {$[18]$} \\
& $510 \mathrm{GPa}$ & & & {$[19]$} \\
$\mathrm{Kr}$ & $310 \mathrm{GPa}$ & $4 \mathrm{p}^{6}$ & $(4 \mathrm{p} 4 \mathrm{~d})^{6}$ & {$[19]$} \\
$\mathrm{Xe}$ & $>130 \mathrm{GPa}$ & $5 \mathrm{p}^{6}$ & $(5 \mathrm{p} 5 \mathrm{~d})^{6}$ & {$[8]$} \\
\hline \hline
\end{tabular}


対しネオンの場合には $2 \mathrm{p}$ と混成する軌道はひとつ上 の主量子数をもつ $3 \mathrm{~d}$ であり、それが $2 \mathrm{p}$ とオーバーラ ップする圧力ははるかに高いものとなることが予測さ れている [16,17]。いっぽうへリウムでは最外款電子 が 1s、オーバーラップする軌道は $2 \mathrm{p}$ となり、他の希 ガス固体金属とは多くの点でちがったふるまいをする ことが予想される。

ネオンの高圧実験は非常に少ない。Hemley らは 110 $\mathrm{GPa}$ までX線回折実験をおこない、ネオンが fcc 構造 の絶縁体であることを報告している [20]。

アルゴンの $80 \mathrm{GPa}$ までのX線回折実験 [21] および $33 \mathrm{GPa}$ までのブリルアン散乱実験 [22] ではアルゴン は fcc 相のままである。

クリプトンはキセノンと同じように高圧下で fcc 相 が不安定となって hcp 相があらわれるのではないかと 考えられるが、X線回折実験 [23]、ブリルアン散乱実 験 [24] およびX線吸収実験（EXAFS）[25] からは 55 GPa まで fcc 相のままである。最近 Kwon らにより第 一原理計算がなされ、アルゴンとクリプトンはそれぞ れ $220 \mathrm{GPa} 、 130 \mathrm{GPa}$ で fcc から hcp に転移すると予 測された [19]。彼らはさらに hcp 相のアルゴン、クリ プトンの金属化圧力をそれぞれ $510 \mathrm{GPa} 、 310 \mathrm{GPa}$ と 見積もっている。

\section{4. ヘリウム}

ヘリウムの高圧実験は現在のところ 金属化の観点よ りはむしろ融解曲線と相図の興味からおこなわれてい る。ヘリウム原子は軽いので量子効果の影響にも興味 が持たれる。初期の頃からヘリウムの高圧実験をおこ なっていたパリ大学のグループはダイヤモンドセル中 で顕微鏡観察をおこないへリウムの融解曲線を求めた [26]。その結果室温 $11.65 \mathrm{GPa}$ に融解曲線の小さな異 常を見いだしこれが固体相内での相転移境界とつなが っているのではないかと提案した [27]。しかしその後 の室温高圧下での単結晶 X 線回折実験ではこの圧力で ヘリウムは hcp 構造であることがしめされた $[28,29] 。$ ヘリウムは低圧低温下で hcp 構造をとることを考える
と、この融解曲線の異常は融点付近に存在する fcc 相 と hcp 相の転移境界であるとも考えられるが、今後の 研究が必要である。バンド計算からはへリウムの金属 化圧力は $11.2 \mathrm{TPa}$ と見積もられている [15]。この圧力 は木星型惑星の中心圧力よりはるかに高く、金属へリ ウムは惑星内部にも存在していないだろう。

\section{5. アルカリハライド、アルカリ土類カルコゲナイド}

希ガス固体の金属化と関連してアルカリハライド（I - VII 化合物）やアルカリ土類カルコゲナイド（II - VI 化合物）の金属化が調べられている。これら化合物中 の陽イオンと陰イオンは希ガス原子と同じ電子配置一 閉款構造一をしているために、高圧下ではバンドオー バーラップによる金属化をするものと考えられている。 ヨウ化セシウムは $70-110 \mathrm{GPa}$ で金属化し [30-36]、 また結晶構造が最終的に hcp になる点もキセノンと類 似している[37]。ヨウ化セシウムはキセノンにくらべ 常圧でのバンドギャップが小さいために（6.2 eV）、 低圧力で金属化がおこる。またバンドギャップは直接 型のまま閉じる[38]。このほかアルカリ土類カルコゲ ナイドでも同じような実験が行われている。Table 3 に 報告された関連化合物の金属化圧力を一覧にした。

Table 3. Experimental metallization pressures of alkali halide and alkaline earth chalcogenides.

\begin{tabular}{lcc}
\hline \hline & $P_{\mathrm{m}}(\mathrm{GPa})$ & Ref. \\
\hline CsI & 70 & {$[30]$} \\
& 110 & {$[36]$} \\
BaSe & 52 & {$[39]$} \\
BaTe & 20 & {$[40]$} \\
& 27 & {$[41]$} \\
SrTe & 55 & {$[41]$} \\
\hline \hline
\end{tabular}

\section{6. 展望}

希ガス固体の金属化は理論的に興味ある主題であり、 
また天体内部との関連からも興味がもたれる。しかし 1989 年以後、現在までにほとんど実験的進展はない。 これは水素の金属化に多くの実験家が携わっているこ とにくらべると対照的である。水素は二原子分子のま ま金属化するであろうと言われているが、それ以前に 分子性固体の中で構造相転移があり金属化の過程は複 雑である。いっぼう希ガスは二原子分子を作らない点 で状況が単純だ。ダイヤモンドアンビルセルの圧力発 生能力がさらに大きく進歩した現在、希ガス固体の金 属化があたらしい視点で研究されることを期待しよう。

\section{参考文献}

[1] Rare Gas Solids, 2 vols., ed. M.L. Klein and J.A. Venables, Academic Press, London, 1976.

[2] 浅海勝征、日本物理学会誌 38, 203-206 (1983), " 固 体 Xe の圧力誘起金属化を探る"；浅海勝征、月刊フ イジクス 4, 444-448 (1983), "固体 Xe およびCsI にお ける圧力誘起絶縁体一金属転移を探る".

[3] D.A. Nelson and A.L. Ruoff, Phys. Rev. Lett. 42, 383 -386 (1979), "Metallic xenon at static pressures".

[4] K. Asaumi, T. Mori, and Y. Kondo, Phys. Rev. Lett. 49, 837-840 (1982), "Effect of very high pressure on the optical absorption edge in solid Xe and its implication for metallization".

[5] K. Syassen, Phys. Rev. B25, 6548-6550 (1982), "Optical absorption of solid xenon at high pressure".

[6] J.M. Besson, J.-P. Itie, G. Weill, and I. Makarenko, J. Physique - LETTRES 43, L401-L404 (1982), "Optical properties of Xe under very high pressure".

[7] I. Makarenko, G. Weill, J.P. Itie, and J.M. Besson, Phys. Rev. B26, $7113-7115$ (1982), "Optical observation on xenon up to $63 \mathrm{GPa}$ ".

[8] M. Ross and A.K. McMahan, Phys. Rev. B21, 1658 1664 (1980), "Condensed xenon at high pressure".

[9] のちに彼らはこの時の圧力値を $100 \mathrm{GPa}$ 以上と修 正している。K.S. Chan, T.L. Huang, T.A. Grzybowski, T.J. Whetten, and A.L. Ruoff, Phys. Rev. B26, 7116-
7118 (1982), "Pressure present during metallization of xenon".

[10] K. Asaumi, Phys. Rev. B29, 7026-7029 (1984), "High-pressure $\mathrm{x}$-ray diffraction study of solid xenon and its equation of state in relation to metallization transition".

[11] A.N. Zisman, I.V. Aleksandrov, and S.M. Stishov, Phys. Rev. B 32, 484-487 (1985), "X-ray study of equations of state of solid xenon and cesium iodide at pressures up to $55 \mathrm{GPa}$ ":

[12] A.P. Jephcoat, H.-k. Mao, L.W. Finger, D.E. Cox, R.J. Hemley, and C.-s. Zha, Phys. Rev. Lett. 59, 26702673 (1987), "Pressure-induced structural phase transitions in solid xenon".

[13] K. A. Goettel, J.H. Eggert, I.F. Silvera, and W.C. Moss, Phys. Rev. Lett. 62, 665-668 (1989), "Optical evidence for the metallization of xenon at 132(5) GPa".

[14] R. Reichlin, K. Brister, M. Ross, A.K. McMahan, S. Martin, Y.K Vohra, and A.L. Ruoff, Phys. Rev. Lett. 62 , 669-672 (1989), "Evidence for the insulator-metal transition in xenon from optical, $x$-ray, and band-structure studies to $170 \mathrm{GPa}$ ".

[15] D.A. Young, A.K. McMahan, and M. Ross, Phys. Rev. B 24, 5119-5127 (1981), "Equation of state and melting curve of helium to very high pressure".

[16] J. Hama, Phys. Lett. 105A, 303-306 (1984), "Anomalously high metallization pressure of solid neon".

[17] J.C. Boettger, Phys. Rev. B33, 6788-6791 (1986), "Equation of state and metallization of neon".

[18] A.K. McMahan, Phys. Rev. B33, 5344-5349 (1984), "Structural transitions and metallization in compressed solid argon".

[19] I. Kwon, L.A. Collins, J.D. Kress, and N. Troullier, Phys. Rev. B52, 15165-15169 (1995), "First-principles study of solid $\mathrm{Ar}$ and $\mathrm{Kr}$ under high compression".

[20] R.J. Hemley, C.S. Zha, A.P. Jephcoat, H.K. Mao, L.W. Finger, and D.E. Cox, Phys. Rev. B39, 1182011827 (1989), "X-ray diffraction and equation of state of 
solid neon to $110 \mathrm{GPa}^{\prime \prime}$.

[21] M. Ross, H.K. Mao, P.M. Bell, and J.A. Xu, J. Chem. Phys. 85, 1028-1033 (1986), "The equation of state of dense argon: A comparison of shock and static studies".

[22] M. Grimsditch, P. Loubeyre, and A. Polian, Phys. Rev. B33, $7192-7200$ (1986), "Brillouin scattering and three-body forces in argon at high pressures".

[23] I.V. Aleksandrov, A.N. Zisman, and S.M. Stishov, Zh. Eksp. Teor. Fiz. 92, 657 (1987) [Sov. Phys. JETP 65, 371 (1987)], "An investigation of the equation of state of the isoelectronic substances $\mathrm{CsI}$ - $\mathrm{Xe}$ and $\mathrm{RbBr}-\mathrm{Kr}$. Phase transition in CsI and RbI".

[24] A. Polian, J.M. Besson, M. Grimsditch, and W.A. Grosshans, Phys. Rev. B39, 1332-1336 (1989), "Solid krypton: Equation of state and elastic properties".

[25] A. Polian, J.P. Itie, E. Dartyge, A. Fontaine, and G. Tourillon, Phys. Rev. B39, 3369-3373 (1989), "X-ray absorption spectroscopy on solid krypton up to $20 \mathrm{GPa}^{\prime \prime}$.

[26] J.M. Besson and J.P. Pinceaux, Science 206, $1073-$ 1075 (1979), "Melting of helium at room temperature and high pressure".

[27] P. Loubeyre, J.M. Besson, J.P. Pinceaux, and J.P. Hansen Phys. Rev. Lett. 49, 1172-1175 (1982), "Highpressure melting curve of ${ }^{4} \mathrm{He}^{\prime \prime}$.

[28] H.K. Mao, R.J. Hemley, Y. Wu, A.P. Jephcoat, L.W. Finger, C.S. Zha, and W.A. Bassett, Phys. Rev. Lett. 60 , 2649-2652 (1988), "High-pressure phase diagram and equation of state of solid helium from single-crystal x-ray diffraction to $23.3 \mathrm{GPa}^{\prime \prime}$.

[29] P. Loubeyre, R. LeToullec, J.P. Pinceaux, H.K. Mao, J. Hu, and R.J. Hemley, Phys. Rev. Lett. 7 1, 2272-2275 (1993), "Equation of state and phase diagram of solid ${ }^{4} \mathrm{He}$ from single-crystal $x$-ray diffraction over a large P-T domain".

[30] K. Asaumi and Y. Kondo, Solid State Commun. 40 , 715-718 (1981), "Effect of very high pressure on the optical absorption spectra in CsI".
[31] E. Knittle and R. Jeanloz, Science 22 3, 53-56 (1984), "Structural and bonding changes in cesium iodide at high pressures".

[32] I.N. Makarenko, A.F. Goncharov, and S.M. Stishov, Phys. Rev. B29, 6018-6019 (1984), "Optical absorption spectra of cesium iodide (CsI) at pressures up to $60 \mathrm{GPa}^{\prime \prime}$. [33] J.P. Itie, A. Polian, and J.M. Besson, Phys. Rev. B30, 2309-2311 (1984), "Optical-absorption edge of CsI up to $58 \mathrm{GPa}^{\prime \prime}$.

[34] Y.K. Vohra, S.T. Weir, K.E. Brister, and A.L. Ruoff, Phys. Rev. Lett. 55, 977-979 (1985), "Band-overlap metallization of cesium iodide".

[35] Q. Williams and R. Jeanloz, Phys. Rev. Lett. 56, 163164 (1986), "Measurements of CsI band-gap closure to 93 GPa".

[36] R. Reichlin, M. Ross, S. Martin, and K.A. Goettel, Phys. Rev. Lett. 56, 2858-2860 (1986), "Metallization of CsI".

[37] H.K. Mao, Y. Wu, R.J. Hemley, L.C. Chen, J.F. Shu, L.W. Finger, and D.E. Cox, Phys. Rev. Lett. 64, 17491752 (1990), "High-pressure phase transition and equation of state of CsI".

[38 ] S. Satpathy, N.E. Christensen, and O. Jepsen, Phys. Rev. B32, 6793-6799 (1985), "Metallization of CsI under pressure: Theoretical results".

[39] S.T. Weir, Y.K. Vohra, and A.L. Ruoff, Phys. Rev. B35, 874-876 (1987), 'Pressure-induced metallization of BaSe".

[40] T.A. Grzybowski and A.L. Ruoff, Phys. Rev. Lett. 53 , 489-492 (1984), "Band-overlap metallization of BaTe".

[41] K. Syassen, N.E. Christensen, H. Winzen, K. Fischer, and J. Evers, Phys. Rev. B35, $4052-4059$ (1987), "Optical response and band-structure calculations of alkaline-earth tellurides under pressure".

[1996 年 5 月 28 日受理] 